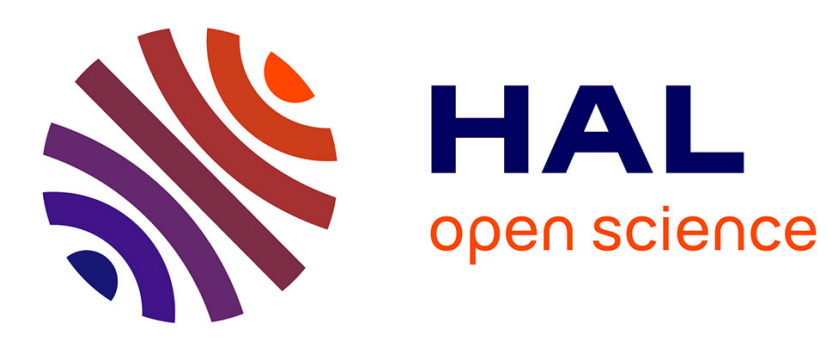

\title{
A new chlorite geothermometer for diagenetic to low-grade metamorphic conditions
}

Franck Bourdelle, Teddy Parra, Christian Chopin, Olivier Beyssac

\section{To cite this version:}

Franck Bourdelle, Teddy Parra, Christian Chopin, Olivier Beyssac. A new chlorite geothermometer for diagenetic to low-grade metamorphic conditions. Contributions to Mineralogy and Petrology, 2013, 165 (4), pp.723-735. 10.1007/s00410-012-0832-7 . hal-02270198

\section{HAL Id: hal-02270198 \\ https://hal.sorbonne-universite.fr/hal-02270198}

Submitted on 23 Aug 2019

HAL is a multi-disciplinary open access archive for the deposit and dissemination of scientific research documents, whether they are published or not. The documents may come from teaching and research institutions in France or abroad, or from public or private research centers.
L'archive ouverte pluridisciplinaire HAL, est destinée au dépôt et à la diffusion de documents scientifiques de niveau recherche, publiés ou non, émanant des établissements d'enseignement et de recherche français ou étrangers, des laboratoires publics ou privés. 


\section{$1 \quad$ Revision 1}

2 Title: A new chlorite geothermometer for diagenetic to low-grade metamorphic conditions 3

4 Authors: Franck Bourdelle ${ }^{\mathrm{a}, \mathrm{b}, \mathrm{c}}$, Teddy Parra $^{\mathrm{a}}$, Christian Chopin $^{\mathrm{b}}$, Olivier Beyssac ${ }^{\mathrm{c}}$ 5

6 Mailing addresses of the relevant institutions:

a IFP Energies Nouvelles, 1\&4 avenue de Bois Préau, 92852 Rueil-Malmaison cedex, France

9 b Ecole normale supérieure - CNRS, Laboratoire de Géologie, 24 rue Lhomond, 75231 Paris 10 cedex 05, France

$11{ }^{\mathrm{c}}$ IMPMC, UPMC-CNRS, Case courrier 115, 4 Place Jussieu, 75252 Paris cedex 05, France 12

13 Corresponding authors:

14 1. Franck Bourdelle

15 Present mailing address: IMPMC, UPMC-CNRS, Case courrier 115, 4 Place Jussieu, 75252

16 Paris cedex 05, France

17 E-mail address: franck.bourdelle@gmail.com

18 Phone number: + 33144272560

19 Fax number: + 33144275152

\section{Teddy Parra}

22 Mailing address: IFP Energies Nouvelles, $1 \& 4$ avenue de Bois Préau, 92852 Rueil-

23 Malmaison cedex, France

24 E-mail address: teddy.parra@ifpen.fr

Phone number: + 33147527367

\section{Abstract}

The evolution of chlorite composition with temperature (and pressure) serves as basis to a number of chlorite chemical thermometers, for which the oxidation state of iron has been recognised as a recurrent issue, especially at low temperature $(T)$. A new chlorite geothermometer that does not require prior $\mathrm{Fe}^{3+}$ knowledge is formulated, calibrated on 161 analyses with well constrained $T$ data covering a wide range of geological contexts, and tested here for low- $T$ chlorites $\left(T<350^{\circ} \mathrm{C}\right.$ and pressures below $\left.4 \mathrm{kbar}\right)$. The new solid-solution model used involves six end-member components (the $\mathrm{Mg}$ and Fe end-members of 'Al-free 
chlorite S', sudoite and amesite) and so accounts for all low- $T$ chlorite compositions; ideal mixing on site is assumed, with an ordered cationic distribution in tetrahedral and octahedral sites.

Applied to chlorite analyses from three distinct low- $T$ environments for which independent $T$ data are available (Gulf Coast, Texas; Saint Martin, Lesser Antilles; Toyoha, Hokkaido), the new pure- $\mathrm{Fe}^{2+}$ thermometer performs at least as well as the recent models, which require an estimate of $\mathrm{Fe}^{3+}$ content. This relief from the ferric iron issue, combined with the simple formulation of the semi-empirical approach, makes the present thermometer a very practical tool, well suited for, e.g., the handling of large analytical datasets - provided it is used in the calibration range $\left(T<350^{\circ} \mathrm{C}, P<4\right.$ kbar $)$.

Keywords: Chlorite, Geothermometry, Diagenesis, Low-grade metamorphism, Solid-solution.

\section{Introduction}

Chlorites are ubiquitous in most diagenetic and metamorphic rocks (Foster 1962; Cathelineau 1988; Laird 1988; De Caritat et al. 1993; Vidal et al. 2001). Their wide compositional variations, through the effect of the three main substitutions $\mathrm{Fe}^{2+}=\mathrm{Mg}$, Tschermak $\mathrm{Al}^{\mathrm{IV}} \mathrm{Al}^{\mathrm{VI}}=\mathrm{Si}\left(\mathrm{Mg}, \mathrm{Fe}^{2+}\right)$, and di/trioctahedral $3\left(\mathrm{Mg}, \mathrm{Fe}^{2+}\right)=\square+2 \mathrm{Al}^{\mathrm{VI}}($ where $\square$ represents an octahedral vacancy), is known to be sensitive to the pressure $(P)$ and temperature $(T)$ conditions of formation, to the bulk composition and to the physico-chemical properties of the environment, like activities in the fluid(s) (e.g. Cathelineau and Nieva 1985; Hillier and Velde 1991; Vidal and Parra 2000). This makes chlorites good indicators of rock history and, for this reason, they are the basis of several empirical or thermodynamic methods to estimate $P$-T conditions (e.g. Cathelineau 1988; Hillier and Velde 1991; Walshe 1986; Vidal et al. 2001; Inoue et al. 2009).

Several studies showed however that an empirical approach, in which the temperature is directly linked to chlorite composition, is often inappropriate (e.g. De Caritat et al. 1993; Essene and Peacor 1995; Bourdelle et al. in revision). For example, the empirical calibrations that are based on the $T$-dependent variation of $\mathrm{Al}^{\mathrm{IV}}$ content are easily applicable, but do not account for the influence of bulk-rock composition. Thus, this approach has no generality and can only be applied to a restricted range of geological settings (De Caritat et al. 1993), in spite of the many formulations proposed (Cathelineau and Nieva 1985; Kranidiotis and McLean 1987; Cathelineau 1988; Jowett 1991; Hillier and Velde 1991; Zang and Fyfe 1995; Xie et al. 1997). Thermodynamic methods circumvent this problem, allowing one to account for 
mineral assemblage and/or physicochemical parameters in addition to temperature and pressure (e.g. Walshe 1986; Vidal and Parra 2000; Vidal et al. 2001, 2005, 2006). However, the thermodynamic approach may be also questioned, considering that the large range of compositional variations in chlorites was not properly handled by thermodynamic modelling. In fact, the inaccuracy of this approach is due in most cases to uncertainties in the $P-T$ data employed for the calibration, to the inaccuracy of the thermodynamic properties of chlorites end-members, to the choice of the mixing model, and to the difficulty in measuring the $\mathrm{Fe}^{3+}$ content and in accounting for it in solid-solution models (cf. Grosch et al. 2012).

On this basis, Inoue et al. (2009) proposed a new, better suited low- $T$ geothermometer that does not require the knowledge of end-member thermodynamic properties but includes the effect of $\mathrm{Fe}^{3+}$ content on temperature estimation, thereby requiring independent $\mathrm{Fe}^{3+}$ determination. However, in their comparative study based on high-spatial-resolution analysis, Bourdelle et al. (in revision) obtained some unsatisfactory results with this thermometer for low- $T$ conditions, probably due to the difficulty in obtaining reliable values of $\mathrm{XFe}^{3+}$ at nanometer scale. Indeed, the estimation of $\mathrm{Fe}^{3+}$ content needs either a Mössbauer spectroscopy study (e.g. Beaufort et al. 1992), which involves grinding of the sample and loss of the textural information, or in situ XANES analysis (e.g. Vidal et al. 2006) which remains a complex procedure, or a numerical estimation using an iterative multi-equilibrium calculation (Vidal et al. 2006). Thus, the presence of ferric iron is clearly an important issue.

The present study was undertaken as a continuation of previous works of Vidal et al. (2006), Inoue et al. (2009) and Bourdelle et al. (in revision), with the goal of developing a chlorite geothermometer for diagenetic to low-grade metamorphic conditions but avoiding the problem of estimating the oxidation state of iron in chlorite. The new calibration is based on a bibliographic compilation of data published during the past three decades and addressing a large variety of geological environments. The validity of this geothermometer is then tested by comparison of the results with those obtained with Vidal et al. (2006) and Inoue et al. (2009) thermometers on three other sets of analytical data, for which $\mathrm{Fe}^{3+}$ contents are known: chlorite analytical electron microscope (AEM) analyses from the Gulf Coast (Texas), where $\mathrm{Fe}^{3+}$ content was estimated by multi-equilibrium calculation; chlorite electron-microprobe (EMP) analyses from Saint Martin (Lesser Antilles), where $\mathrm{Fe}^{3+}$ content was estimated by Mössbauer spectroscopy (Beaufort et al. 1992); and chlorite EMP analyses from Toyoha (Hokkaido), where $\mathrm{Fe}^{3+}$ content was estimated by X-ray photoelectron spectroscopy (XPS, Inoue et al. 2010).

\section{Sources of chlorite analyses}


In order to calibrate the new geothermometer on a wide spectrum in terms of $P-T$ conditions, of geological environments and of analytical methods, published data concerning the low- $T$ chlorites and their chemical compositions were screened. The specifications governing the selection of the data were as follows:

- A detailed quantitative analysis of chlorites by EMP or AEM should be available along with temperature and pressure data estimated by independent methods, in the range of 50$350^{\circ} \mathrm{C}$ and below $4 \mathrm{kbar}$. The temperature data were used as published when given with a sufficient level of confidence (i.e. convergence of several thermometric methods or discussion of the obtained data). The pressure data refer to the authors' estimates whenever possible and to indications of geological context ensuring that formation pressure was less than 4 kbar. In case of uncertainty or insufficient level of confidence regarding the $P-T$ data, the analyses were discarded. For instance, some important studies such as Jowett (1991), Zang and Fyfe (1995) and Inoue et al. (2009) had to be discarded because pressure estimates were not available or because temperature data were not assigned to specific chlorite compositions. All relevant published data/studies are summarized in Table 1.

- Only analyses of material that was not identified as detrital by the authors were retained, as in Rahn et al. (1994) study, where authigenic and detrital compositions are identified. All published data summarized in Table 1 are considered as referring to authigenic chlorites.

- Only quartz-bearing samples were considered.

- When these first criteria were met, two additional chemical criteria were applied to exclude contaminated analyses or those that cannot be expressed as a linear combination 
These chlorites are from sandstone core samples from nine wells of the Gulf Coast,

146 Texas. Analyses were obtained with AEM on rock ultrathin sections obtained by focused ion

147 beam (FIB) milling, in accordance with the analytical protocol described by Bourdelle et al.

148 (2012). All details regarding the location and geology methods are given by Bourdelle et al.

149 (in revision). In the following, four analyses of the crystal rim were used for each sample

150 because these compositions were considered to be a good representation of the last steps of

151 dissolution/recrystallisation processes and were assumed to represent the closest approach to

152 the equilibrium composition for the highest $P-T$ conditions. The independently obtained $P-T$

153 formation data are bottom-hole temperature (BHT) and bottom-hole pressure (BHP) data

154 corrected following Kehle (1971) and assumed to be the maximum $P$ - $T$ conditions (100-

$155230^{\circ} \mathrm{C}, 0-1.2 \mathrm{kbar}$ ) undergone by the samples, with an estimated error range of $\pm 20^{\circ} \mathrm{C}$ and

$156 \pm 0.2 \mathrm{kbar}$ (for discussion, see Bourdelle et al. in revision).

157 The chemical composition of the selected Gulf Coast chlorites spans a large range

158 (Table 2), but similar to that reported by previous studies on diagenetic clays (e.g. Curtis et al.

159 1984, 1985; Velde and Medhioub 1988; Hillier and Velde 1991; Jahren and Aagaard 1989,

160 1992; Jahren 1991). If all iron is taken as $\mathrm{Fe}^{2+}$, total $\mathrm{Al}$ contents range from 2.52 to 3.38

161 atoms per formula unit (apfu) based on a 14 oxygen anhydrous basis (which will be used

162 throughout this paper), vacancies from 0.12 to 0.49 apfu while the $\mathrm{Fe}^{2+} /\left(\mathrm{Fe}^{2+}+\mathrm{Mg}^{2+}\right)$ ratio

163 varies between 0.47 and 0.88 (Table 2).

164 The $\mathrm{Fe}^{3+}$ content was estimated using the approach of Vidal et al. (2006), which is

165 based on the convergence of four chlorite-quartz-water equilibria. This method gives the

166 minimum $\mathrm{Fe}^{3+}$ proportion required to reach the best convergence at specific $P-T$ conditions; a

167 maximum $\mathrm{Fe}^{3+}$ proportion can be estimated when the equilibrium convergence is lost. Under

168 low- $T$ conditions, the difference between minimum and maximum $\mathrm{Fe}^{3+}$ contents is small and,

169 therefore, we considered that the minimum $\mathrm{Fe}^{3+}$ content estimated with this approach is a fair

170 approximation of the actual value. The results show that the minimum $\mathrm{Fe}^{3+}$ contents are

171 heterogeneous in the temperature window of the Gulf Coast and range between 5\% and 40\%

172 of total iron. 
Relevant analyses have been published by Beaufort et al. (1992). The samples are from volcanoclastic rocks that were hydrothermally altered by an intrusive quartz-diorite pluton emplaced during the Early Oligocene (Beaufort et al. 1990, 1992). The chlorites used in this study are from three different alteration zones: the epidote + chlorite + quartz assemblage zone (zone 2), the epidote + chlorite + hematite + quartz assemblage zone (zone 3), and the chlorite + phengite + magnetite assemblage zone (as vein, zone 4).

Paleotemperatures were estimated by the fluid-inclusion method, and range between 220 and $340^{\circ} \mathrm{C}$ (Beaufort et al. 1992; Inoue et al. 2009).

Under the assumption that $\mathrm{Fe}_{\text {total }}=\mathrm{Fe}^{2+}$, the $\mathrm{Al}^{\mathrm{IV}}$ content ranges from 0.96 to 1.21 apfu, vacancies from 0.05 to $0.20 \mathrm{apfu}$, and the $\mathrm{Fe}^{2+} /\left(\mathrm{Fe}^{2+}+\mathrm{Mg}^{2+}\right)$ ratio between 0.08 and 0.68. The $\mathrm{XFe}^{3+}$ ratios were estimated by Mössbauer spectroscopy (Beaufort et al. 1992) and the results strongly depend on the metamorphic zones: $25-30 \%$ for zone 2 chlorites, $32 \%$ for zone 3 , and $16 \%$ for zone 4 .

\section{Toyoha chlorites}

The seven analyses used concerning Toyoha chlorites have been published by Inoue et al. (2010) and have been also separated from the literature data because they are associated with precise $\mathrm{XFe}^{3+}$ estimations. These chlorites are from hydrothermally altered rocks in the Toyoha geothermal system, southwestern Hokkaido, Japan, from the propylitic zone and the ore mineralized zone. Paleotemperatures were estimated with Inoue et al. (2009) model and were close both to the homogenisation temperatures of fluid inclusions and the present subsurface temperatures measured through drill holes. They range between 159 and $264^{\circ} \mathrm{C}$. Under the assumption that $\mathrm{Fe}_{\text {total }}=\mathrm{Fe}^{2+}$, the $\mathrm{Al}^{\mathrm{IV}}$ content ranges from 0.85 to 1.20 apfu, $\mathrm{Al}^{\mathrm{VI}}$ from 1.08 to 1.33 apfu and vacancies from 0.25 to $0.40 \mathrm{apfu}$. The $\mathrm{Fe}^{3+}$ contents were estimated by X-ray photoelectron spectroscopy (XPS) and the results are homogeneous and range from 0.13 to 0.17 for the ore mineralized zone and from 0.20 to 0.26 for the propylitic zone.

\section{Formulation of a new geothermometer, as an extension of previous methods}

To establish a new thermometer, it is necessary to define the cationic repartition in the structure, the activity model used and appropriate solid solutions by the choice of relevant end-member components. In this study, the focus is on chlorites formed at low-temperatures, i.e. between 50 and $350^{\circ} \mathrm{C}$, which have high Si content and octahedral vacancies due to 
$\mathrm{Si} \square \mathrm{R}^{2+}{ }_{-2}$ exchange (e.g. Hillier and Velde 1991). Vidal et al. (2006), building on Vidal et al.

212 (2001) and Vidal et al. (2005) studies, chose clinochlore, daphnite, Mg-sudoite, Fe-amesite

213 and Mg-amesite as end-members. This excludes Si-rich ( $\mathrm{Si}>3 \mathrm{apfu}$ ) compositions (Table 3)

214 and therefore, many of the diagenetic chlorites. Inoue et al. (2009) preferred to consider a

215 compositional space defined by the $\mathrm{Mg}$-chlorite $\mathrm{S}, \mathrm{Mg}$-amesite, daphnite and $\mathrm{Mg}$-sudoite end-

216 members (Table 3). This choice seems appropriate to cover all the compositional range of

217 low- $T$ chlorites, especially because the octahedral vacancies rarely exceed 1 apfu. However,

218 all iron is then concentrated in one trioctahedral end-member component, daphnite.

219 Considering these observations, the chlorite solid solution is defined in this study with six 220 end-members: (Fe, Mg)-chlorite $\mathrm{S}$, (Fe, Mg)-sudoite and (Fe, Mg)-amesite (Table 3).

The activity model depends on the cationic site repartition in the structure; according to the ideal structure of the trioctahedral chlorite defined by Bailey (1988), the basic layer consists in a regular alternation of talc $\left\{\mathrm{M} 1(\mathrm{M} 2)_{2}\left[(\mathrm{~T} 1)_{2}(\mathrm{~T} 2)_{2}\right] \mathrm{O}_{10}(\mathrm{OH})_{2}\right\}$ and brucite layers $\left\{(\mathrm{M} 3)_{2} \mathrm{M} 4(\mathrm{OH})_{6}\right\}$. Each crystallographic site entails some cationic preferences, but two assumptions remain possible: that of an ordered distribution (Vidal et al. 2005, 2006) and that of random mixing (Inoue et al. 2009). Vidal et al. (2006) assumed that $\mathrm{Al}^{\mathrm{IV}}$ is restricted to T2 sites, vacancies to M1, Al ${ }^{\mathrm{VI}}$ fills M4 first then M1 and eventually M2-M3, while Fe-Mg fills M2-M3 sites then M1. Inoue et al. (2009) borrowed the distinction between T1 and T2 sites, with $\mathrm{Al}^{\mathrm{IV}}$ exclusively on $\mathrm{T} 2$, but assumed a random mixing on all octahedral sites. The ordered approach seems to be closest to Bailey's (1988) observations and makes Vidal's thermometer less sensitive to $\mathrm{Fe}^{3+}$ content, as shown in a comparative study (Bourdelle et al. in revision). For this reason, an ordered model was adopted in this study to describe the compositional variations of low- $T$ chlorite, as follows. To account for 'chlorite $S$ ' endmembers, we unified M1 and M4 sites (Table 4). Tetrahedral $\mathrm{Al}$ is restricted to T2 sites, vacancies to $\mathrm{M} 1-\mathrm{M} 4, \mathrm{Al}^{\mathrm{VI}}$ resulting from Tschermak exchange fills $\mathrm{M} 1-\mathrm{M} 4$, excess $\mathrm{Al}^{\mathrm{VI}}$ is in M2-M3, Fe-Mg fills predominantly M2-M3 sites then M1-M4 (Table 4). In accordance with Vidal et al. (2005, 2006), Fe/Mg and Si/Al ratio are considered equal in the M1-M4 and M2M3 sites, and T2 sites respectively. Regarding the special case of $\mathrm{Fe}^{3+}$, Vidal et al. (2005, 2006) restricted it to $\mathrm{M} 4$ and Inoue et al. (2009) exchanged it with $\mathrm{Al}^{\mathrm{VI}}$ in all M sites (with an identical $\mathrm{Fe}^{3+} / \mathrm{Fe}^{2+}$ ratio), whereas the new model does not consider it. 
246 where $a_{\text {ideal }}$ is the ideal part of the activity, $r_{m}$ and $X_{m}$ are the number and the mole fraction of

247 cation $m$ on the site $s$, and $k$ is the normalization constant defined by:

$$
k=\prod_{s} \prod_{m}\left(\frac{n_{s}}{r_{m}}\right)^{r_{m}}
$$

As done by Inoue et al. (2009), neglecting the non-ideal contribution of the site 252 mixing, a new semi-empirical $T=f(\log K)$ geothermometer can be formulated with our 253 specific choice of ordered solid-solution model, where $K$ is the equilibrium constant of the 254 end-member-component reaction describing the chlorite + quartz equilibrium.

255 From a thermodynamic point of view, for any balanced chemical reaction involving $j$ endmembers, the equilibrium condition can be expressed by:

where $\Delta G_{r}^{0}$ is the Gibbs free energy of reaction, $R$ is the gas constant and $K$ is the chlorite + quartz equilibrium constant, which can be written as:

$$
K=\prod_{j}\left(a_{\text {ideal }}\right)_{j}^{v_{j}}
$$

with $v_{j}$ as the stoichiometric reaction coefficient of phase $j$. The equations for the calculations of end-member ideal activities are listed in Table 3, according to the cationic site mixing repartition detailed in Table 4 . With three end-members, the chlorite + quartz assemblage can be described in the Mg system by the reaction:

272 If the effect of pressure is ignored, in accord with the $P<4$ kbar data selection, and the

273 change in heat capacity is assumed to be naught, the $\log K$ for the reaction defined above can 274 be expressed by: 
$\log K=\frac{-\Delta G_{r}^{0}}{2.303(R \cdot T)}=\frac{A}{T}+B=\log \left(\frac{a_{M g-A m}^{3} \cdot a_{S i O_{2}}^{7} \cdot a_{H_{2} O}^{4}}{a_{M g-C h l s} \cdot a_{M g-S u d}^{3}}\right)$

$=3 \log a_{M g-A m}-\log a_{M g-C h l S}-3 \log a_{M g-S u d}+7 \log a_{S i O_{2}}+4 \log a_{H_{2} O}$

where $T$ is temperature and $A$ and $B$ constants, with $A=\Delta H \div(2.303 \times R)$ and

$B=\Delta S \div(2.303 \times R)$, given the $\Delta C p$ approximation.

\section{Calibration of the thermometer}

The new thermometer is calibrated from the relation between the logarithm of the equilibrium constant and $1 / T$, using the 161 low- $P$ chlorite compositions $(P<4$ kbar $)$ and their estimated formation temperature according to the literature (Table 1). For those calculations, we assumed that $a \mathrm{SiO}_{2}=1, a \mathrm{H}_{2} \mathrm{O}=1$ and $\mathrm{Fe}_{\text {total }}=\mathrm{Fe}^{2+}$. From the regression analysis, we obtain the new linear equation:

$$
\log K=-\frac{9400}{T(K)}+23.40
$$

A quadratic regression yields the equation

$$
\log K=\frac{11185729}{T(K)^{2}}-\frac{56598}{T(K)}+72.3
$$

which provides a better fit in the range $300-350^{\circ} \mathrm{C}$, but has no physical basis (cf. equation 6) and so should not be used outside the range $150-350^{\circ} \mathrm{C}$. The relationship between reference temperatures (literature data) and temperatures calculated with the new thermometer for the calibration dataset is shown in Figure 2. The standard deviation from the 1:1 line is almost $46^{\circ} \mathrm{C}$ when using the combination of equations (7) and (8) (cf. Fig 2) and $65^{\circ} \mathrm{C}$ when using equation (7). However, the standard deviation calculation is biased by the 6 calculated temperatures exceeding $450^{\circ} \mathrm{C}$ (Fig 2) and is variable with $T$ : in fact, the standard deviation is data scattering is similar to those obtained when testing the Inoue et al. (2009) and Vidal et al. (2006) models on the same literature dataset $\left(\mathrm{XFe}^{3+}\right.$ estimated with the Vidal et al. 2006 model). Therefore, we consider that the correlation between estimated and expected $T$ is satisfactory. 
Testing the new geothermometer

309

310

Using equation (7) applied to the chlorite + quartz assemblage, the formation temperatures of Gulf Coast, Saint Martin and Toyoha chlorites were estimated assuming all iron is ferrous and 1 for $\mathrm{H}_{2} \mathrm{O}$ activity. In fact, in all cases, the values of $\mathrm{H}_{2} \mathrm{O}$ activity in the fluid are unknown and the assumption $a \mathrm{H}_{2} \mathrm{O}=1$ seems to be reasonable in diagenetic to lowgrade metamorphic conditions (Inoue et al. 2009), but remains locally questionable. The assumption $a \mathrm{SiO}_{2}=1$ is justified in the case of quartz-bearing rocks.

The temperatures calculated with equation (7) are plotted (i) versus measured temperatures in Figure 3 for Gulf Coast chlorites, for which the high-spatial-resolution should ensures the best reliability of the analyses, (ii) versus $\mathrm{Al}^{\mathrm{IV}}$ content in Figure 4 for Saint Martin and Toyoha chlorites assumed to be authigenic crystals. The temperatures obtained with the new thermometer range from 91 to $231^{\circ} \mathrm{C}$, for an expected range of $102-232^{\circ} \mathrm{C}$ for the Gulf Coast samples. Few analyses (BHT $180^{\circ} \mathrm{C}$ ) give too low a temperature (Figure 3 ) suggesting that they do not represent highest- $T$ equilibrium composition. Generally, the measured and calculated temperatures are very close, with less than $20^{\circ} \mathrm{C}$ difference. For Saint Martin chlorites, the calculated temperatures range from 172 to $351^{\circ} \mathrm{C}$ (Figure 4 ) for an expected $220-340^{\circ} \mathrm{C}$ whereas for Toyoha chlorites, the temperatures range from 159 to $301^{\circ} \mathrm{C}$ for an expected $159-264^{\circ} \mathrm{C}$ (a single calculated temperature is outside the expected range). In all cases, the new equation appears to be highly reliable to obtain sensible temperature values, despite the assumption that all iron is ferrous and regardless of the rock-type considered.

\section{Discussion}

Suitability of chlorite analyses for calibration and testing

As pointed out by Hillier and Velde (1992), De Caritat et al. (1993), Jiang et al. (1994) and Essene and Peacor (1995), part of the compositional variations measured for low- $T$ chlorites may be ascribed to contamination by kaolinite, or to interstratification with berthierine or smectite, which might also lead to erroneous structural formulae and an overestimation of vacancy contents (vacancies are then considered as an analytical artifact). The interstratification with smectite is assumed to be negligible here because only analyses with $<1 \%$ wt total $\mathrm{Na}_{2} \mathrm{O}+\mathrm{CaO}+\mathrm{K}_{2} \mathrm{O}$ were selected, both for calibration and for testing, almost $90 \%$ of which actually have $\mathrm{Na}_{2} \mathrm{O}+\mathrm{CaO}+\mathrm{K}_{2} \mathrm{O}<0.5 \%$ wt. The interstratification with 
342 the $7 \AA$-phase berthierine, which is a common phenomenon in low- $T$ chlorites (Xu and

343 Veblen, 1996), is difficult to distinguish chemically from a true solid-solution without high-

344 resolution structural control. In this respect, the use of a high-resolution analytical protocol

345 (with AEM) for the Gulf Coast chlorites allows for avoiding the 7 or $10 \AA$ A-layer and quartz

346 contaminations; it shows that octahedral vacancies in low- $T$ chlorite are an actual feature and

347 that their amount varies with $T$. Therefore, the deficit in octahedral cations ( $<6$ apfu)

348 observed under all conditions (diagenetic or metamorphic) in the absence of significant

349 smectite or mica contamination is real, and should be amplified in structural formula

350 recalculation when accounting for $\mathrm{Fe}^{3+}$ content, which is not negligible for low- $T$ chlorites

351 (Beaufort et al. 1992).

352 An issue is the reliability of AEM data compared to EMP. Only three AEM databases 353 were used here: Jahren and Aagaard (1992) and Lopez-Munguira et al. (2002) for calibration, 354 and Gulf Coast chlorites analyses for testing. Lopez-Munguira et al. (2002) showed that the 355 analyses obtained with both methods are highly similar. Bourdelle et al. (2012) also show the 356 suitability of a FIB-AEM protocol to obtain chlorite analyses with a level of confidence 357 similar to EMP analyses: this is the protocol used here to analyse the Gulf Coast chlorites. On 358 this basis, we consider that the reliability of the analyses used for calibration or testing is not 359 affected by the applied analytical method.

360 In a broader perspective and for practical purposes, we aimed at the largest possible 361 database for calibration, offering a wide coverage of geological parameters, like lithology, 362 temperature gradient, kinetics, fluid regimes, oxidation state, chlorite composition (including $363 \mathrm{XFe}^{3+}$ ), chlorite precursors, impurities and analytical contaminations (insofar as they are of 364 limited extent). This was considered the best way to limit the effect of each parameter, with 365 the aim of a general thermometer for low- $T$ chlorites. Therefore, all the data used for 366 thermometer calibration were considered as suitable, provided they met the imposed chemical 367 criteria. As a result, the database used in this study is the largest ever gathered for low- $T$ 368 chlorite thermometry, with 161 analyses for $T<350^{\circ} \mathrm{C}, P<4 \mathrm{kbar}$, of which 94 analyses are 369 for $T<250^{\circ} \mathrm{C}$, compared to 23 analyses (for $T<350^{\circ} \mathrm{C}$ ) for Inoue et al. (2009; from Vidal et 370 al. 2001 appendix), with 11 analyses for $T<250^{\circ} \mathrm{C}$.

Comparison with recent chlorite thermometers thermometer (using the linear equation (7) and the assumption $\mathrm{Fe}_{\text {total }}=\mathrm{Fe}^{2+}$ ) are compared in

376 Figure 5 to the two main non-empirical models (Vidal et al. 2005, 2006; Inoue et al. 2009) for 
which $\mathrm{Fe}^{3+}$ content is taken into account. Note that many analyses were automatically excluded in Vidal's model by their Si content higher than 3 apfu. The thermodynamic model of Walshe (1986) was not considered, as it does not allow for Si contents lower than 3 apfu. For the Gulf Coast chlorites, Vidal et al. (2005, 2006) and Inoue et al. (2009) models give substantially similar results, with a range of formation temperatures of $84-317^{\circ} \mathrm{C}$ and $113-325^{\circ} \mathrm{C}$, respectively (Figure 5a). The two sets of results are very similar (Figure 5a, inset) and are very close to those obtained with equation (7). However, some analyses near $\sim 200^{\circ} \mathrm{C}$ branch off the 1:1 trend, yielding overestimated temperatures with Inoue and Vidal models. These analyses are characterised by high $\mathrm{Al}$ content and low $\mathrm{XFe}^{3+}$ (according to Vidal procedure) in contrast to the high- $T$ analyses of the 1:1 trend, which have low Al content and high $\mathrm{XFe}^{3+}(\sim 35-40 \%)$. Important is that, regardless of these compositional variations including $\mathrm{XFe}^{3+}$, the present thermometer, unlike the two others, yields a single trend of temperatures for these two groups, consistent with measured temperatures (cf. Figure 3).

For the Saint Martin chlorites, Vidal et al. (2005, 2006) and Inoue et al. (2009) models yield results in the ranges $50-321^{\circ} \mathrm{C}$ and $172-313^{\circ} \mathrm{C}$, respectively. In this case, most of the temperatures obtained with Vidal's model are underestimated and differ from the two other thermometers, whereas the newly proposed equation (7) gives temperatures that are very similar to those obtained with Inoue's model.

For Toyoha chlorites, the situation is similar to the Saint Martin case, with a scatter of results obtained with Vidal's thermometer $\left(70-265^{\circ} \mathrm{C}\right)$, and results of the two other thermometers close to each other and in better agreement with the expected range (159$\left.264^{\circ} \mathrm{C}\right)$.

For each of the three geological fields, the results are similar and in the expected temperature windows for Inoue's and the newly proposed model, whereas Vidal's model gives more disparate, often underevaluating results. These differences in calculated temperatures can be explained by the choices of end-members (and site assignment of iron) and of calibration basis (more weight of the high- $T$, low- $\mathrm{Fe}^{3+}$ analyses in Vidal and Inoue databases). The excellent agreement between Inoue and Vidal's models in Figure 5a (inset) in contrast to Figure $5 \mathrm{~b}$ and $\mathrm{c}$ (insets) is not fortuitous as this is the sole case for which $\mathrm{XFe}^{3+}$ input ratios are obtained with Vidal et al. (2006) iterative method. In summary, the comparison of the new thermometer and Vidal and Inoue's models shows that equation (7), based on an ordered distribution and the $\mathrm{Fe}_{\text {total }}=\mathrm{Fe}^{2+}$ assumption, performs well in the case of low- $T$ chlorites. 
The semi-empirical approach, based on a reaction, appears as a good alternative solution between a purely thermodynamic treatment, which requires knowledge of the many end-member and mixing properties (as Vidal et al. 2006), and the purely empirical approach, which does not consider the bulk composition (as Cathelineau 1988). As regards the cationic distribution, Inoue et al. (2009) suggest that one reason for the inaccuracy in low- $T$ domain of the Vidal et al. (2001) model, rearranged by Vidal et al. $(2005,2006)$, is the ordered site occupancy. This statement is derived from the polytype distribution (Ia, Ib, IIb) according to the metamorphic grade. However, in the absence of univocal information, in particular on the validity of each cationic distribution model according to polytype, we prefer to base the new thermometer on a semi-ordered distribution. The results presented above show that it gives at least as reliable estimates as Inoue's disordered model for the three geological fields of Gulf Coast, Saint Martin and Toyoha. The cation distribution model is therefore not the main issue for chlorite thermometry. On the basis of the above comparisons, it appears that the calibration ( $T$ range and compositional space) and the choice of end-members determine the pertinence of the various models.

\section{Testing the effect of non-ideality}

As done by Inoue et al. (2009), the non-ideal contribution of the site mixing was neglected in the present study. This assumption was required to calibrate a semi-empirical $T=$ $f(K)$ geothermometer, but it needs to be evaluated, considering that sudoite and trioctahedral chlorite may coexist in equilibrium in a few cases (in low- $T$, low- $P$ or low- $T$, high- $P$ aluminous metapelites, e.g. Theye et al. 1992). For the assumption of ideal mixing to be tenable, one must verify that (i) for a given chlorite composition, the contribution of the nonideality varies linearly with $1 / T$, and (ii) at given $T$, the variation of the non-ideal contribution with chlorite composition is small, so that the net effect of non-ideality is grossly linear in $T$ and so makes a linear calibration possible.

$$
K=\prod_{j}\left(a_{\text {ideal }} \cdot \gamma\right)_{j}^{v_{j}} \text { with } \gamma_{j}=\prod_{s} \prod_{m} \gamma_{m}^{n_{s}}
$$


where, for a $j$ component, $\gamma$ is the non-ideality coefficient, $n_{s}$ is the multiplicity of the site $s$ and $m$ are the relevant cations. The $\log / \ln K$ can be expressed as the sum of an ideal and a non-ideal part:

$$
R \cdot T \cdot \ln K=R \cdot T \cdot \ln \left(\prod_{j} a_{\text {ideal }}\right)_{j}+R \cdot T \cdot \ln \left(\prod_{j} \gamma\right)_{j}
$$

Neglecting ternary and quaternary interactions, the non-ideal contribution may be written:

$$
n_{s} \cdot R \cdot T \cdot \ln \gamma_{m}=\sum W_{i j} \cdot X_{i} \cdot X_{j} \cdot\left[\frac{Q_{m}}{X_{m}}-1\right]
$$

where $W_{i j}$ are the Margules parameters, $X_{m}$ is the mole fraction of cation $m$ and $Q_{m}$ is the number of $i, j$ subscripts that are equal to $m$. Clearly, from this formalism, the non-ideal contribution in the $\log / \ln K$ calculation is linear in $1 / T$ for a fixed composition.

For the second point, Bourdelle (2011) tested the new model for various chlorite compositions and $P-T$ conditions. Starting with an average composition and an approximation of Margules parameters defined by Vidal et al. (2001, 2005, 2006), he used equations (10) and (11) and the defined semi-ordered distribution to calculate the non-ideal contribution for several temperatures at given $P$, considering symmetric binary interactions. The author introduced variation in the composition and conditions, by varying the $\mathrm{XSi}_{\mathrm{T} 2}, \mathrm{XMg}$ (ratio), $\mathrm{X} \square$ and pressure. The results of these tests are plotted in Figure 6 and show, in the range of $100-350^{\circ} \mathrm{C}$ and neglecting the $W(\mathrm{M} 2+\mathrm{M} 3)$ parameters (following Vidal et al. 2005, 2006) as well as the pressure factor, that the variations of $\mathrm{XMg}$ ratio affect only very slightly the variation of $\log / \ln K$ with $1 / T$. This holds especially if the tested chlorite compositions are only considered in the range of temperatures to which they refer (i.e. the Si-rich composition, $\mathrm{Si}=3.4$ apfu, mainly characterises very low- $T$ chlorites, contrary to the Si-poor composition, $\mathrm{Si}=2.6 \mathrm{apfu})$. The non-ideal contribution mainly affects the $y$-intercept of the $\ln K=f(1 / \mathrm{T})$ curve, which does not preclude a linear calibration. Thus, we conclude that the variation of the non-ideal contribution with composition (in the classical range of diagenetic chlorites) is sufficiently small for the linearity of $\log / \ln K$ in $1 / T$ to be grossly preserved. Therefore, for the $P-T$ domain and the composition range investigated here, calibration on a linear basis is justified and, actually, any effect of non-ideality is implicitly taken into account in the thermometer equation. 

calculation recognized as the Tschermak substitution with a contribution of di-trioctahedral substitution at low $T$. This decrease of octahedral vacancies with increasing $T$ is therefore built in any calibration database, particularly when the database includes lower- $T$ chlorites. Besides, accounting for $\mathrm{Fe}^{3+}$ in the structural formula recalculation on a fixed oxygen basis arithmetically reduces the number of cations, and implies an increase of octahedral vacancies, which in turn links indirectly $\mathrm{Fe}^{3+}$ content and temperature in any thermometric formulation. However, this effect of $\mathrm{Fe}^{3+}$ remains subordinate with respect to the main compositional evolutions with $T$ mentioned above (compare Figures 6a and 6b in Inoue et al. 2009). Accordingly, variations of the chlorite + quartz $\log K$ remain negatively correlated with $1 / T$, regardless of the assumption made on the oxidation state of iron. This justifies calibrating a chlorite thermometer on one or the other assumption, i.e. $\mathrm{Fe}_{\mathrm{total}}=\mathrm{Fe}^{2+}$ or real $\mathrm{Fe}^{3+}$ values. $\mathrm{A}$ calibration based on the latter choice should lead to higher precision, but calibration based on the former case may be a good trade-off of practicability and simplicity $\left(\mathrm{Fe}^{3+}\right.$ content not required) against precision. Admittedly, the sudoite activity is poorly evaluated, i.e. biased by the non consideration of $\mathrm{Fe}^{3+}$ content, but this possible bias is built in the calibration. The best demonstration of the validity of this trade-off is the success of the thermometer presented here in its applications to various geological contexts.

\section{Conclusion}

Various concerns have been raised on the relevance, applicability and precision of chlorite thermometry (e.g. De Caritat et al. 1993; Jiang et al. 1994; Essene and Peacor 1995). However, recent developments (e.g. Vidal et al. 2001, 2005, 2006; Inoue et al. 2009) have led to a reappraisal of this technique and to new opportunities in exploiting the information contained in chlorite composition. Comparative studies (e.g. Inoue et al. 2009; this paper) have yet pointed out that order-disorder, compositional space, non-ideality and $\mathrm{Fe}^{3+}$ effects may be limitations and/or sources of disagreement. The approach developed here, compensating these sources of variability through the use of a large database for linear calibration, proves successful in its application to low- $T$ chlorites. This success may lie in the 
non-ideality or $\mathrm{Fe}^{3+}$ content), or is not significantly affected by them, the backbone of the variation being the combined effects of the Tschermak and di-trioctahedral substitutions. The new geothermometer allows one to account for all the low- $T$ chlorite compositions, especially Si-rich compositions that characterize diagenetic chlorites. The comparison of the new thermometer with the recent ones that require $\mathrm{Fe}^{3+}$ content estimation shows that it is possible to obtain reliable results $\left( \pm 20^{\circ} \mathrm{C}\right.$ in most cases) without any measurement or assumption on the $\mathrm{Fe}^{3+}$ content. In this respect, the present semi-empirical thermometer is a much practical tool, well suited for, e.g., the handling of large analytical datasets in exploration geology. However, it should be kept in mind that the new equation proposed here is only valid over its calibration range $\left(T<350^{\circ} \mathrm{C}, P<4 \mathrm{kbar}\right)$ and that any use out of these limits, in particular in the metamorphic realm, is not recommended - mainly because of the assumptions on the heat-capacity and volume changes of the reaction, the pressure effect and the water activity in the new model, which may no longer be valid. Above $350^{\circ} \mathrm{C}$, the thermometry of Vidal et al. $(2005,2006)$ remains probably the most convenient approach.

\section{Acknowledgements}

We are most grateful to the materials characterization department of IFP Energies NouvellesLyon, in particular to F. Moreau, and to the laboratory of CP2M-Université Aix-Marseille, for technical advice. The discussions and comments of the journal editor Jochen Hoefs, of Atsuyuki Inoue and two anonymous reviewers are gratefully acknowledged. Thanks are also extended to K. Milliken, S. Dutton and J. Donnelly of Bureau of Economic Geology at Austin, Texas. This study was financially supported by IFP Energies Nouvelles, CNRS and ENS Paris.

\section{References}

Bailey SW (1988) Chlorites: structures and crystal chemistry. In: Bailey SW (eds) Hydrous

$$
\text { Phyllosilicates (Exclusive of Micas), vol 19. Reviews in Mineralogy. Mineralogical }
$$
Society of America, Washington D.C., pp 347-403

Beaufort D, Patrier P, Meunier A, Ottaviani MM (1992) Chemical variations in assemblages including epidote and/or chlorite in the fossil hydrothermal system of Saint Martin (Lesser Antilles). J Volcanol Geoth Res 51:95-114 
Beaufort D, Westercamp D, Legendre O, Meunier A (1990) The fossil hydrothermal system of Saint Martin: (1) Geology and lateral distribution of alterations. Journal of Volcanology and Geothermal Research 40:219-243

Bevins RE, Robinson D, Rowbotham G (1991) Compositional Variations in Mafic Phyllosilicates from Regional Low-Grade Metabasites and Application of the Chlorite Geothermometer. J Metamorph Geol 9 (6):711-721

Boles JR, Francks GS (1979) Clay diagenesis in Wilcox sandstones of Southwest Texas: Implications of smectite diagenesis on sandstone cementation. J Sediment Petrol 49:55-70 Bourdelle F (2011) Thermobarométrie des phyllosilicates dans les séries naturelles:
Conditions de la diagenèse et du métamorphisme de bas degré. Thesis, University of ParisSud, Orsay

Bourdelle F, Parra T, Beyssac O, Chopin C, Moreau F (2012) Ultrathin section preparation of phyllosilicates by Focused Ion Beam milling for quantitative analysis by TEM-EDX. Appl Clay Sci 59-60:121-130

Bourdelle F, Parra T, Chopin C, Beyssac O, Vidal O (in revision) Clay minerals thermometry: A comparative study based on high-spatial-resolution analyses of illite and chlorite in Gulf Coast sandstones (Texas, USA). Am Min

Cathelineau M (1988) Cation site occupancy in chlorites and illites as a function of temperature. Clay Miner 23 (4):471-485

Cathelineau M, Nieva D (1985) A chlorite solid solution geothermometer. The Los Azufres (Mexico) geothermal system. Contrib Mineral Petrol 91 (3):235-244

Curtis CD, Hughes CR, Whiteman JA, Whittle CK (1985) Compositional variation within some sedimentary chlorites and some comments on their origin. Mineral Mag 49:375-386 Curtis CD, Ireland BJ, Whiteman JA, Mulvaney R, Whittle CK (1984) Authigenic chlorites: Problems with chemical analysis and structural formula calculation. Clay Miner 19:471481

De Caritat P, Hutcheon I, Walshe JL (1993) Chlorite geothermometry: A review. Clay Clay Miner 41 (2):219-239

Essene EJ, Peacor DR (1995) Clay mineral thermometry - A critical perspective. Clay Clay

$$
\text { Miner } 43 \text { (5):540-553 }
$$

Foster MD (1962) Interpretation of the composition and a classification of the chlorites. US Geological Survey Professional Paper 414-A:33

Grosch EG, Vidal O, Abu-Alam T, McLoughlin N (2012) P-T Constraints on the metamorphic evolution of the Paleoarchean Kromberg type-Section, Barberton Greenstone Belt, South Africa. J Petrol 53 (3): 513-545. 
580

581

582

583

584

585

586

587

588

589

590

591

592

593

594

595

596

597

598

599

600

601

602

603

604

605

606

607

608

609

611

612

610 geochronological case study from the Bukk Mts. (NE Hungary). J Struct Geol 30 (2):159613 massive sulfide deposit, Matagami, Quebec. Econ Geol 82 (7):1898-1911

Helgeson HC, Delany JM, Nessbitt HW, Bird DK (1978) Summary and critique of the thermodynamic properties of rock-forming minerals. Am J Sci 278A:1-229

Hillier S, Velde B (1991) Octahedral occupancy and the chemical-composition of diagenetic (low-temperature) chlorites. Clay Miner. 26 (2):149-168

Hillier S, Velde B (1992) Chlorite interstratified with a 7 A mineral: An example from offshore Norway and possible implications for the interpretation of the composition of diagenetic chlorites. Clay Miner. 27:475-486

Hutcheon I (1990) Clay carbonate reactions in the Venture area, Scotian Shelf, Nova Scotia, Canada. The Geochemical society, Special Publication, pp 199-212

Inoue A, Kurokawa K, Hatta T (2010) Application of chlorite geothermometry to hydrothermal alteration in Toyoha geothermal system, Southwestern Hokkaido, Japan. Resour Geol 60 (1):52-70. doi:10.1111/j.1751-3928.2010.00114.x

Inoue A, Meunier A, Patrier-Mas P, Rigault C, Beaufort D, Vieillard P (2009) Application of Chemical Geothermometry to Low-Temperature Trioctahedral Chlorites. Clay Clay Miner 57 (3):371-382

Jahren JS (1991) Evidence of Ostwald ripening related recrystallization of chlorites from reservoir rocks offshore Norway. Clay Miner 26:169-178

Jahren JS, Aagaard P (1989) Compositional variations in diagenetic chlorites and illites, and relationships with formation-water chemistry. Clay Miner 24:157-170

Jahren JS, Aagaard P (1992) Diagenetic Illite-Chlorite Assemblages in Arenites .1. Chemical Evolution. Clay Clay Miner 40 (5):540-546

Jiang WT, Peacor DR, Buseck PR (1994) Chlorite geothermometry? - Contamination and apparent octahedral vacancies. Clay Clay Mineral 42 (5):593-605

Jowett EC (1991) Fitting iron and magnesium into the hydrothermal chlorite geothermometer. Paper presented at the GAC/MAC/SEG Joint annual meeting, Toronto, Canada, 27-29 May 1991

Kehle RO (1971) Geothermal survey of North America. American Association of Petroleum Geologists, 31p.

Koroknai B, Arkai P, Horvath P, Balogh K (2008) Anatomy of a transitional brittle-ductile

shear zone developed in a low- $T$ meta-andesite tuff: A microstructural, petrological and

176

12 Kranidiotis P, McLean WH (1987) Systematics of chlorite alternation at the Phelps Dodge 
Laird J (1988) Chlorites: metamorphic petrology. In: Bailey SW (eds) Hydrous Phyllosilicates (Exclusive of Micas), vol 19. The Mineralogical Society of America, Washington D.C., pp 405-453

Lopez-Munguira A, Nieto F, Morata D (2002) Chlorite composition and geothermometry: a comparative HRTEM/AEM-EMPA-XRD study of Cambrian basic lavas from the Ossa Morena Zone, SW Spain. Clay Miner 37 (2):267-281

Mas A, Guisseau D, Mas PP, Beaufort D, Genter A, Sanjuan B, Girard JP (2006) Clay minerals related to the hydrothermal activity of the Bouillante geothermal field (Guadeloupe). J Volcanol Geoth Res 158 (3-4):380-400

McDowell SD, Elders WA (1980) Authigenic layer silicate minerals in borehole Elmore 1, Salton Sea geothermal field, California, USA. Contrib Mineral Petrol 74:293-310

Powell R (1978) Equilibrium Thermodynamics in Petrology: An Introduction. Harper \& Row, London

Rahn M, Mullis J, Erdelbrock K, Frey M (1994) Very Low-Grade Metamorphism of the Taveyanne Greywacke, Glarus Alps, Switzerland. J Metamorph Geol 12 (5):625-641

Schmidt D, Schmidt ST, Mullis J, Mahlmann RF, Frey M (1997) Very low grade metamorphism of the Taveyanne formation of western Switzerland. Contrib Mineral Petrol 129 (4):385-403

Theye T, Seidel E, Vidal O (1992) Carpholite, sudoite, and chloritoid in low-grade highpressure metapelites from Crete and the Peloponnese, Greece. Eur J Mineral (4): 487-507

Velde B, Medhioub M (1988) Approach to chemical equilibrium in diagenetic chlorites. Contrib Mineral Petrol 98:122-127

Vidal O, De Andrade V, Lewin E, Munoz M, Parra T, Pascarelli S (2006) P-T-deformation$\mathrm{Fe}^{3+} / \mathrm{Fe}^{2+}$ mapping at the thin section scale and comparison with XANES mapping: application to a garnet-bearing metapelite from the Sambagawa metamorphic belt (Japan). J Metamorph Geol 24 (7):669-683

Vidal O, Parra T (2000) Exhumation paths of high-pressure metapelites obtained from local equilibria for chlorite-phengite assemblages. Geol J 35 (3-4):139-161

Vidal O, Parra T, Trotet F (2001) A thermodynamic model for Fe-Mg aluminous chlorite using data from phase equilibrium experiments and natural pelitic assemblages in the $100^{\circ}$ to $600{ }^{\circ} \mathrm{C}, 1$ to $25 \mathrm{~kb}$ range. Am J Sci 301 (6):557-592

Vidal O, Parra T, Vieillard P (2005) Thermodynamic properties of the Tschermak solid solution in Fe-chlorite: Application to natural examples and possible role of oxidation. Am Mineral 90 (2-3):347-358 
648 Walshe JL (1986) A six-component chlorite solid solution model and the conditions of 649 chlorite formation in hydrothermal and geothermal systems. Econ Geol 81:681-703

650 Xie XG, Byerly GR, Ferrell RE (1997) IIb trioctahedral chlorite from the Barberton

651 greenstone belt: Crystal structure and rock composition constraints with implications to

652 geothermometry. Contrib Mineral Petrol 126 (3):275-291

$653 \mathrm{Xu} \mathrm{H}$, Veblen DR (1996) Interstratification and other reaction microstructures in the chlorite-

654 berthierine series. Contrib Mineral Petrol 124:291-301

655 Zang W, Fyfe WS (1995) Chloritization of the Hydrothermally Altered Bedrock at the

656 Igarape-Bahia Gold Deposit, Carajas, Brazil. Miner Deposita 30 (1):30-38

657

658

Tables

659

660 Table 1 Published data and methods to estimate temperature for the analyses that have been

661 used to calibrate the new thermometer

662

\begin{tabular}{ll}
\hline Study & Temperature estimation methods \\
\hline Boles and Franks (1979) & in situ temperature measurement \\
McDowell and Elders (1980) & in situ temperature measurement \\
Cathelineau (1988) & in situ temperature measurement, data compilation \\
Hutcheon (1990) & in situ temperature measurement \\
Bevins et al. (1991) & chl-thermometry, mineral assemblages \\
Jahren and Aagaard (1992) & in situ temperature measurement \\
De Caritat et al. (1993) & data compilation, chl-thermometry, carbonates thermometry \\
Rahn et al. (1994) & chl-thermometry, vitrinite reflectance, fluid inclusions \\
Schmidt et al. (1997) & chl-thermometry, fluid inclusions, isotopy ( $\left.\Delta^{18} \mathrm{O}_{\mathrm{qz}-\mathrm{calcite}}\right)$, IC and CC index \\
Xie et al. (1997) & chl-polytypism, chl-thermometry \\
Lopez-Munguira et al. (2002) & chl-thermometry \\
Mas et al. (2006) & in situ temperature measurement \\
Koroknai et al. (2008) & chl-thermometry, mineral assemblages \\
\hline
\end{tabular}

663

664 Table 2 AEM analyses of Gulf Coast chlorites (crystal rims analyses). Elements contents are 665 given in atom per formula unit $(\mathrm{O}=14 \mathrm{apfu})$. All iron is considered as ferrous

666

\begin{tabular}{lcccccccccc}
\hline \multirow{2}{*}{ Sample } & AZ\#159 & AZ\#159 & AZ\#159 & AZ\#159 & ST\#470 & ST\#470 & ST\#470 & CK\#2 & CK\#2 & CK\#2 \\
& 9230 & 9230 & 9230 & 9230 & 10717 & 10717 & 10717 & 11924 & 11924 & 11924 \\
\hline Analysis & chl10 & chl17 & chl30 & chl28 & chl27 & chl29 & chl30 & chl47 & chl50 & chl54 \\
BHT $\left({ }^{\circ} \mathrm{C}\right)$ & 102 & 102 & 102 & 102 & 121 & 121 & 121 & 129 & 129 & 129 \\
BHP (bars) & 300 & 300 & 300 & 300 & 590 & 590 & 590 & 660 & 660 & 660 \\
\hline
\end{tabular}




\begin{tabular}{lllllllllll}
$\mathrm{Si}$ & 2.98 & 2.95 & 2.95 & 2.91 & 3.08 & 3.19 & 3.01 & 2.96 & 2.90 & 2.91 \\
$\mathrm{Ti}$ & 0.01 & 0.00 & 0.00 & 0.00 & 0.00 & 0.00 & 0.01 & 0.01 & 0.01 & 0.00 \\
$\mathrm{Al}$ & 2.76 & 2.76 & 2.75 & 2.86 & 2.55 & 2.60 & 2.77 & 2.90 & 2.98 & 2.86 \\
$\mathrm{Fe}^{2+}$ & 2.18 & 2.20 & 2.34 & 2.46 & 2.81 & 2.55 & 2.53 & 2.45 & 2.37 & 2.53 \\
$\mathrm{Mn}$ & 0.00 & 0.01 & 0.02 & 0.00 & 0.02 & 0.02 & 0.01 & 0.00 & 0.01 & 0.00 \\
$\mathrm{Mg}$ & 1.65 & 1.71 & 1.60 & 1.39 & 1.15 & 1.11 & 1.22 & 1.18 & 1.31 & 1.29 \\
$\mathrm{Ca}$ & 0.03 & 0.01 & 0.00 & 0.00 & 0.01 & 0.00 & 0.02 & 0.01 & 0.00 & 0.01 \\
$\mathrm{Na}$ & 0.00 & 0.00 & 0.01 & 0.03 & 0.00 & 0.03 & 0.00 & 0.02 & 0.00 & 0.00 \\
$\mathrm{~K}$ & 0.05 & 0.05 & 0.06 & 0.05 & 0.07 & 0.05 & 0.06 & 0.06 & 0.06 & 0.07 \\
\hline
\end{tabular}

667

\begin{tabular}{lcccccccccc}
\hline \multirow{2}{*}{ Sample } & CK\#2 & CK\#2 & CK\#2 & CK\#2 & LA\#1 & LA\#1 & LA\#1 & LA\#1 & ST\#356 & ST\#356 \\
& 12196 & 12196 & 12196 & 12196 & 13559 & 13559 & 13559 & 13559 & 14501 & 14501 \\
\hline Analysis & chl20 & chl18 & chl19 & chl21 & chl23 & chl20 & chl11 & chl17 & chl36 & chl34 \\
BHT $\left({ }^{\circ} \mathrm{C}\right)$ & 135 & 135 & 135 & 135 & 149 & 149 & 149 & 149 & 166 & 166 \\
$\mathrm{BHP}($ bars $)$ & 690 & 690 & 690 & 690 & 850 & 850 & 850 & 850 & 800 & 800 \\
\hline $\mathrm{Si}$ & 2.96 & 3.05 & 3.02 & 3.02 & 2.88 & 2.86 & 2.83 & 2.78 & 2.84 & 2.71 \\
$\mathrm{Ti}$ & 0.00 & 0.02 & 0.01 & 0.00 & 0.00 & 0.00 & 0.00 & 0.00 & 0.00 & 0.00 \\
$\mathrm{Al}$ & 2.85 & 2.83 & 2.91 & 2.81 & 2.91 & 2.92 & 2.95 & 3.07 & 2.85 & 3.00 \\
$\mathrm{Fe}{ }^{2+}$ & 2.45 & 2.38 & 2.38 & 2.39 & 3.28 & 3.36 & 3.41 & 3.28 & 2.05 & 2.07 \\
$\mathrm{Mn}$ & 0.00 & 0.02 & 0.00 & 0.01 & 0.01 & 0.00 & 0.00 & 0.03 & 0.00 & 0.00 \\
$\mathrm{Mg}$ & 1.34 & 1.18 & 1.20 & 1.30 & 0.53 & 0.48 & 0.47 & 0.49 & 1.96 & 1.98 \\
$\mathrm{Ca}$ & 0.00 & 0.04 & 0.01 & 0.01 & 0.02 & 0.00 & 0.01 & 0.03 & 0.00 & 0.00 \\
$\mathrm{Na}$ & 0.00 & 0.00 & 0.00 & 0.00 & 0.03 & 0.02 & 0.00 & 0.02 & 0.03 & 0.00 \\
$\mathrm{~K}$ & 0.00 & 0.03 & 0.01 & 0.08 & 0.03 & 0.04 & 0.04 & 0.03 & 0.03 & 0.05 \\
\hline
\end{tabular}

668

\begin{tabular}{lcccccccccc}
\hline \multirow{2}{*}{ Sample } & CW\#1 & CW\#1 & CW\#1 & CW\#1 & WR\#C1 & WR\#C1 & WR\#C1 & FR\#1 & FR\#1 & FR\#1 \\
& 14277 & 14277 & 14277 & 14277 & 17805 & 17805 & 17805 & 18946 & 18946 & 18946 \\
\hline Analysis & chl13 & chl14 & chl32 & chl31 & chl13 & chl18 & chl16 & chl26 & chl30 & chl28 \\
BHT $\left({ }^{\circ} \mathrm{C}\right)$ & 191 & 191 & 191 & 191 & 191 & 191 & 191 & 204 & 204 & 204 \\
$\mathrm{BHP}$ (bars) & 750 & 750 & 750 & 750 & 1050 & 1050 & 1050 & 1150 & 1150 & 1150 \\
\hline $\mathrm{Si}$ & 2.68 & 2.68 & 2.65 & 2.63 & 2.98 & 2.97 & 2.90 & 2.88 & 2.87 & 2.87 \\
$\mathrm{Ti}$ & 0.00 & 0.02 & 0.01 & 0.01 & 0.00 & 0.00 & 0.00 & 0.00 & 0.00 & 0.01 \\
$\mathrm{Al}$ & 3.38 & 3.22 & 3.24 & 3.21 & 3.00 & 2.91 & 2.95 & 2.64 & 2.62 & 2.60 \\
$\mathrm{Fe}$ & 2.68 & 2.98 & 3.00 & 3.01 & 2.38 & 2.39 & 2.48 & 2.01 & 2.08 & 2.07 \\
$\mathrm{Mn}$ & 0.20 & 0.00 & 0.00 & 0.00 & 0.00 & 0.00 & 0.01 & 0.01 & 0.01 & 0.00 \\
$\mathrm{Mg}$ & 0.82 & 0.79 & 0.80 & 0.85 & 1.08 & 1.26 & 1.28 & 2.24 & 2.19 & 2.23 \\
$\mathrm{Ca}$ & 0.05 & 0.00 & 0.00 & 0.04 & 0.01 & 0.02 & 0.00 & 0.00 & 0.02 & 0.01 \\
$\mathrm{Na}$ & 0.00 & 0.00 & 0.07 & 0.00 & 0.03 & 0.00 & 0.01 & 0.00 & 0.00 & 0.00 \\
$\mathrm{~K}$ & 0.04 & 0.04 & 0.00 & 0.03 & 0.03 & 0.05 & 0.02 & 0.05 & 0.06 & 0.07 \\
\hline
\end{tabular}

669

\begin{tabular}{lllllllll}
\hline \multirow{2}{*}{ Sample } & FR\#1 & AL\#1 & AL\#1 & AL\#1 & AL\#1 & AL\#1 & AL\#1 & AL\#1 \\
& 18946 & 19110 & 19110 & 19110 & 19110 & 20711 & 20711 & 20711 \\
\hline Analysis & chl29 & chl17 & chl18 & chl27 & chl25 & chl31 & chl28 & chl29
\end{tabular}




\begin{tabular}{lcccccccc}
$\mathrm{BHT}\left({ }^{\circ} \mathrm{C}\right)$ & 204 & 216 & 216 & 216 & 216 & 232 & 232 & 232 \\
$\mathrm{BHP}$ (bars) & 1150 & 1150 & 1150 & 1150 & 1150 & 1200 & 1200 & 1200 \\
\hline $\mathrm{Si}$ & 2.84 & 2.66 & 2.64 & 2.66 & 2.61 & 2.94 & 2.88 & 2.85 \\
$\mathrm{Ti}$ & 0.01 & 0.00 & 0.00 & 0.00 & 0.00 & 0.01 & 0.00 & 0.00 \\
$\mathrm{Al}$ & 2.64 & 3.21 & 3.21 & 3.13 & 3.16 & 2.52 & 2.60 & 2.64 \\
$\mathrm{Fe}^{2+}$ & 2.15 & 2.47 & 2.53 & 2.43 & 2.44 & 2.74 & 2.95 & 2.93 \\
$\mathrm{Mn}$ & 0.00 & 0.02 & 0.00 & 0.00 & 0.00 & 0.00 & 0.00 & 0.00 \\
$\mathrm{Mg}$ & 2.11 & 1.38 & 1.32 & 1.49 & 1.55 & 1.50 & 1.36 & 1.36 \\
$\mathrm{Ca}$ & 0.01 & 0.01 & 0.02 & 0.01 & 0.00 & 0.00 & 0.00 & 0.00 \\
$\mathrm{Na}$ & 0.02 & 0.00 & 0.00 & 0.03 & 0.00 & 0.02 & 0.00 & 0.02 \\
$\mathrm{~K}$ & 0.07 & 0.01 & 0.07 & 0.04 & 0.05 & 0.06 & 0.07 & 0.06 \\
\hline
\end{tabular}

670

671 Table 3 Ideal activities of solid-solution end-members used in the calculation of the three

672 chlorite geothermometers

673

End-members Chemical formula*

(abbreviations) (half formula unit)
Equilibrium / Ideal activities ${ }^{\dagger}$

Vidal et al. (2005, 2006) model

Thermodynamic formalism

Clinochlore (Clin)

$\left(\mathrm{AlMg}_{5}\right)\left(\mathrm{Si}_{3} \mathrm{Al}\right)$

Daphnite (Daph)

$\mathrm{Mg}$-Amesite (Mg-Am)

$\mathrm{Fe}$-Amesite (Fe-Am)

Mg-Sudoite (Mg-Sud)
$\left(\mathrm{AlFe}_{5}\right)\left(\mathrm{Si}_{3} \mathrm{Al}\right)$

$\left(\mathrm{Al}_{2} \mathrm{Mg}_{4}\right)\left(\mathrm{Si}_{2} \mathrm{Al}_{2}\right)$

$\left(\mathrm{Al}_{2} \mathrm{Fe}_{4}\right)\left(\mathrm{Si}_{2} \mathrm{Al}_{2}\right)$

$\left(\mathrm{Al}_{3} \mathrm{Mg}_{2}\right)\left(\mathrm{Si}_{3} \mathrm{Al}\right)$
$2 \mathrm{Clin}+3 \mathrm{Mg}-\mathrm{Sud}=4 \mathrm{Mg}-\mathrm{Am}+7 \mathrm{Qtz}+4 \mathrm{H}_{2} \mathrm{O}$

$=4\left(\mathrm{X}_{\mathrm{Mg}, \mathrm{M} 1}\right)\left(\mathrm{X}_{\mathrm{Mg}, \mathrm{M} 2+\mathrm{M} 3}\right)^{4}\left(\mathrm{X}_{\mathrm{Si}, \mathrm{T} 2}\right)\left(\mathrm{X}_{\mathrm{Al}, \mathrm{T} 2}\right)$

$=4\left(\mathrm{X}_{\mathrm{Fe}, \mathrm{M} 1}\right)\left(\mathrm{X}_{\mathrm{Fe}, \mathrm{M} 2+\mathrm{M} 3}\right)^{4}\left(\mathrm{X}_{\mathrm{Si}, \mathrm{T} 2}\right)\left(\mathrm{X}_{\mathrm{Al}, \mathrm{T} 2}\right)$

$=64\left(\mathrm{X}_{\square, \mathrm{M} 1}\right)\left(\mathrm{X}_{\mathrm{Al}, \mathrm{M} 2+\mathrm{M} 3}\right)^{2}\left(\mathrm{X}_{\mathrm{Mg}, \mathrm{M} 2+\mathrm{M} 3}\right)^{2}\left(\mathrm{X}_{\mathrm{Si}, \mathrm{T} 2}\right)\left(\mathrm{X}_{\mathrm{Al}, \mathrm{T} 2}\right)$

$=4\left(\mathrm{X}_{\square, \mathrm{M} 1}\right)\left(\mathrm{X}_{\mathrm{Al}, \mathrm{M} 2+\mathrm{M} 3}\right)^{2}\left(\mathrm{X}_{\mathrm{Mg}, \mathrm{M} 2+\mathrm{M} 3}\right)^{2}\left(\mathrm{X}_{\mathrm{Si}, \mathrm{T} 2}\right)\left(\mathrm{X}_{\mathrm{Al}, \mathrm{T} 2}\right)$

$=\left(\mathrm{X}_{\mathrm{Al}, \mathrm{M} 1}\right)\left(\mathrm{X}_{\mathrm{Mg}, \mathrm{M} 2+\mathrm{M} 3}\right)^{4}\left(\mathrm{X}_{\mathrm{Al}, \mathrm{T} 2}\right)^{2}$

Inoue et al. (2009) model

$T(K)=1 /\left(0.00293-5.13 \times 10^{-4} \times \log K+3.904 \times 10^{-5} \times(\log K)^{2}\right)$

Mg-Chlorite $\mathrm{S}^{\mathrm{a}}(\mathrm{Mg}-\mathrm{Chl} \mathrm{S})$

$\left(\mathrm{Mg}_{6}\right)\left(\mathrm{Si}_{4}\right)$

$\mathrm{Mg}-\mathrm{Chl} \mathrm{S}+3 \mathrm{Mg}-\mathrm{Sud}=3 \mathrm{Mg}-\mathrm{Am}+7 \mathrm{Qz}+4 \mathrm{H}_{2} \mathrm{O}$

Daphnite $^{\text {b }}$ (Daph)

$\left(\mathrm{AlFe}_{5}\right)\left(\mathrm{Si}_{3} \mathrm{Al}\right)$

$=\left(\mathrm{X}_{\mathrm{Mg}, \text { oct }}\right)^{6}\left(\mathrm{X}_{\mathrm{Si}, \mathrm{tet}}\right)^{2}$

$\mathrm{Mg}-$ Sudoite (Mg-Sud)

$\left(\mathrm{Al}_{3} \mathrm{Mg}_{2}\right)\left(\mathrm{Si}_{3} \mathrm{Al}\right)$

$=59.720\left(\mathrm{X}_{\mathrm{Fe}, \text { oct }}\right)^{5}\left(\mathrm{X}_{\mathrm{Al}, \text { oct }}\right)\left(\mathrm{X}_{\mathrm{Si}, \text { et }}\right)\left(\mathrm{X}_{\mathrm{Al}, \text { tet }}\right)$

Mg-Amesite $(\mathrm{Mg}-\mathrm{Am})$

$\left(\mathrm{Al}_{2} \mathrm{Mg}_{4}\right)\left(\mathrm{Si}_{2} \mathrm{Al}_{2}\right)$

$$
=1728\left(\mathrm{X}_{\mathrm{Mg}, \mathrm{oct}}\right)^{2}\left(\mathrm{X}_{\mathrm{Al}, \mathrm{oct}}\right)^{3}\left(\mathrm{X}_{\square, \mathrm{oct}}\right)\left(\mathrm{X}_{\mathrm{Si}, \mathrm{tet}}\right)\left(\mathrm{X}_{\mathrm{Al}, \mathrm{tet}}\right)
$$$$
=45.563\left(\mathrm{X}_{\mathrm{Mg}, \mathrm{oct}}\right)^{4}\left(\mathrm{X}_{\mathrm{Al}, \mathrm{oct}}\right)^{2}\left(\mathrm{X}_{\mathrm{Al}, \mathrm{tet}}\right)^{2}
$$

This study model

$T(K)=9400 /(23.40-\log K)$

Mg-Chlorite S (Mg-Chl S)

$\left(\mathrm{Mg}_{6}\right)\left(\mathrm{Si}_{4}\right)$

$\mathrm{Mg}-\mathrm{Chl} \mathrm{S}+3 \mathrm{Mg}-\mathrm{Sud}=3 \mathrm{Mg}-\mathrm{Am}+7 \mathrm{Qz}+4 \mathrm{H}_{2} \mathrm{O}$

Fe-Chlorite S (Fe-Chl S)

$\left(\mathrm{Fe}_{6}\right)\left(\mathrm{Si}_{4}\right)$

$=\left(\mathrm{X}_{\mathrm{Si}, \mathrm{T} 2}\right)^{2}\left(\mathrm{X}_{\mathrm{Mg}, \mathrm{M} 2+\mathrm{M} 3}\right)^{4}\left(\mathrm{X}_{\mathrm{Mg}, \mathrm{M} 1+\mathrm{M} 4}\right)^{2}$

Mg-Amesite (Mg-Am)

$\left(\mathrm{Al}_{2} \mathrm{Mg}_{4}\right)\left(\mathrm{Si}_{2} \mathrm{Al}_{2}\right)$

$=\left(\mathrm{X}_{\mathrm{Si}, \mathrm{T} 2}\right)^{2}\left(\mathrm{X}_{\mathrm{Fe}, \mathrm{M} 2+\mathrm{M} 3}\right)^{4}\left(\mathrm{X}_{\mathrm{Fe}, \mathrm{M} 1+\mathrm{M} 4}\right)^{2}$

$\mathrm{Fe}$-Amesite (Fe-Am)

$\left(\mathrm{Al}_{2} \mathrm{Fe}_{4}\right)\left(\mathrm{Si}_{2} \mathrm{Al}_{2}\right)$

$=\left(\mathrm{X}_{\mathrm{Al}, \mathrm{T} 2}\right)^{2}\left(\mathrm{X}_{\mathrm{Mg}, \mathrm{M} 2+\mathrm{M} 3}\right)^{4}\left(\mathrm{X}_{\mathrm{Al}, \mathrm{M} 1+\mathrm{M} 4}\right)^{2}$

$\mathrm{Mg}-$ Sudoite (Mg-Sud)

$=\left(\mathrm{X}_{\mathrm{Al}, \mathrm{T} 2}\right)^{2}\left(\mathrm{X}_{\mathrm{Fe}, \mathrm{M} 2+\mathrm{M} 3}\right)^{4}\left(\mathrm{X}_{\mathrm{Al}, \mathrm{M} 1+\mathrm{M} 4}\right)^{2}$

$=256\left(\mathrm{X}_{\mathrm{Si}, \mathrm{T} 2}\right)\left(\mathrm{X}_{\mathrm{Al}, \mathrm{T} 2}\right)\left(\mathrm{X}_{\mathrm{Al}, \mathrm{M} 1+\mathrm{M} 4}\right)$ $\left(\mathrm{X}_{\square, \mathrm{M} 1+\mathrm{M} 4}\right)\left(\mathrm{X}_{\mathrm{Mg}, \mathrm{M} 2+\mathrm{M} 3}\right)^{2}\left(\mathrm{X}_{\mathrm{Al}, \mathrm{M} 2+\mathrm{M} 3}\right)^{2}$ 


\begin{tabular}{|c|c|c|}
\hline Fe-Sudoite (Fe-Sud) & $\left(\mathrm{Al}_{3} \mathrm{Fe}_{2}\right)\left(\mathrm{Si}_{3} \mathrm{Al}\right)$ & $\begin{aligned}= & 256\left(\mathrm{X}_{\mathrm{Si}, \mathrm{T} 2}\right)\left(\mathrm{X}_{\mathrm{Al}, \mathrm{T} 2}\right)\left(\mathrm{X}_{\mathrm{Al}, \mathrm{M} 1+\mathrm{M} 4}\right) \\
& \left(\mathrm{X}_{\square, \mathrm{M} 1+\mathrm{M} 4}\right)\left(\mathrm{X}_{\mathrm{Fe}, \mathrm{M} 2+\mathrm{M} 3}\right)^{2}\left(\mathrm{X}_{\mathrm{Al}, \mathrm{M} 2+\mathrm{M} 3}\right)^{2}\end{aligned}$ \\
\hline
\end{tabular}

674 Note : $X_{j, s}$ is the mole fraction of the $j$ cation on the $s$ site

675 Equivalents in Inoue et al. (2009): ${ }^{\mathrm{a}}$ Al-free chlorite, ${ }^{\mathrm{b}}$ chamosite,${ }^{\mathrm{c}}$ corundophilite. $*$ Structural formula based on

$676 \mathrm{O}_{10}(\mathrm{OH})_{8} \cdot{ }^{\dagger}$ Ideal activities are completed with a non-ideal contribution in the Vidal et al. $(2005,2006)$ model

677

678 Table 4 Chlorite solid-solution end-members and cationic site repartition used in the new

679 geothermometer calculation

680

681

\begin{tabular}{|c|c|c|c|c|c|c|}
\hline End-members & $\mathrm{T} 1(2)$ & $\mathrm{T} 2(2)$ & $\dagger$ & $(\mathrm{M} 2+\mathrm{M} 3)(4)$ & $\dagger$ & $(\mathrm{M} 1+\mathrm{M} 4)$ \\
\hline Mg-Chlorite S & $\operatorname{Si}(2)$ & $\operatorname{Si}(2)$ & & $\operatorname{Mg}(4)$ & & $\operatorname{Mg}(2)$ \\
\hline Fe-Chlorite S & $\operatorname{Si}(2)$ & $\operatorname{Si}(2)$ & & $\mathrm{Fe}(4)$ & & $\mathrm{Fe}(2)$ \\
\hline Mg-Sudoite & $\operatorname{Si}(2)$ & $\mathrm{SiAl}$ & & $\operatorname{Al}(2) \operatorname{Mg}(2)$ & & $\mathrm{Al} \square$ \\
\hline Fe-Sudoite & $\operatorname{Si}(2)$ & $\mathrm{SiAl}$ & & $\operatorname{Al}(2) \mathrm{Fe}(2)$ & & $\mathrm{Al} \square$ \\
\hline Mg-Amesite & $\operatorname{Si}(2)$ & $\mathrm{Al}(2)$ & & $\operatorname{Mg}(4)$ & & $\mathrm{Al}(2)$ \\
\hline Fe-Amesite & $\operatorname{Si}(2)$ & $\mathrm{Al}(2)$ & & $\mathrm{Fe}(4)$ & & $\mathrm{Al}(2)$ \\
\hline $\mathrm{Mg}$ & & & 4 & $\mathrm{Mg}-\mathrm{Mg}_{\mathrm{M} 1}$ & 3 & $\left(\mathrm{Fe}_{\mathrm{M} 1}+\mathrm{Mg}_{\mathrm{M} 1}\right) \times \mathrm{XMg}$ \\
\hline $\mathrm{Fe}$ & & & 4 & $\mathrm{Fe}-\mathrm{Fe}_{\mathrm{M} 1}$ & 3 & $\left(\mathrm{Fe}_{\mathrm{M} 1}+\mathrm{Mg}_{\mathrm{M} 1}\right) \times \mathrm{XFe}$ \\
\hline $\mathrm{Fe}+\mathrm{Mg}$ & & & 2 & $4-\left(\mathrm{Al}^{\mathrm{VI}}-\mathrm{Al}^{\mathrm{IV}}\right)$ & 2 & $2-\left(\mathrm{Al}_{\mathrm{M} 1+\mathrm{M} 4}+\square\right)$ \\
\hline $\mathrm{Al}$ & & $4-\mathrm{Si}$ & \begin{tabular}{|l|}
1 \\
\end{tabular} & $\mathrm{Al}^{\mathrm{VI}}-\mathrm{Al}^{\mathrm{IV}}$ & \begin{tabular}{|l|}
1 \\
\end{tabular} & $\mathrm{Al}^{\mathrm{IV}}$ \\
\hline$\square$ & & & & & 1 & $\left(\mathrm{Al}^{\mathrm{VI}}-\mathrm{Al}^{\mathrm{IV}}\right) / 2$ \\
\hline
\end{tabular}

682

\section{Figures}

684

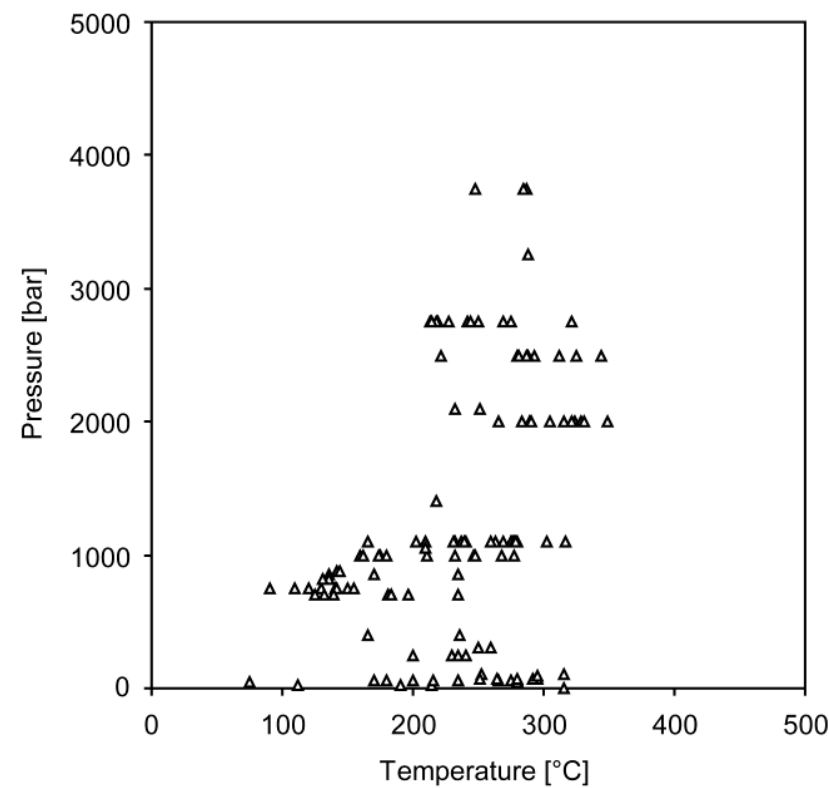

686 Fig. $1 P-T$ data for 161 chlorites analyses compiled from literature (Table 1) 


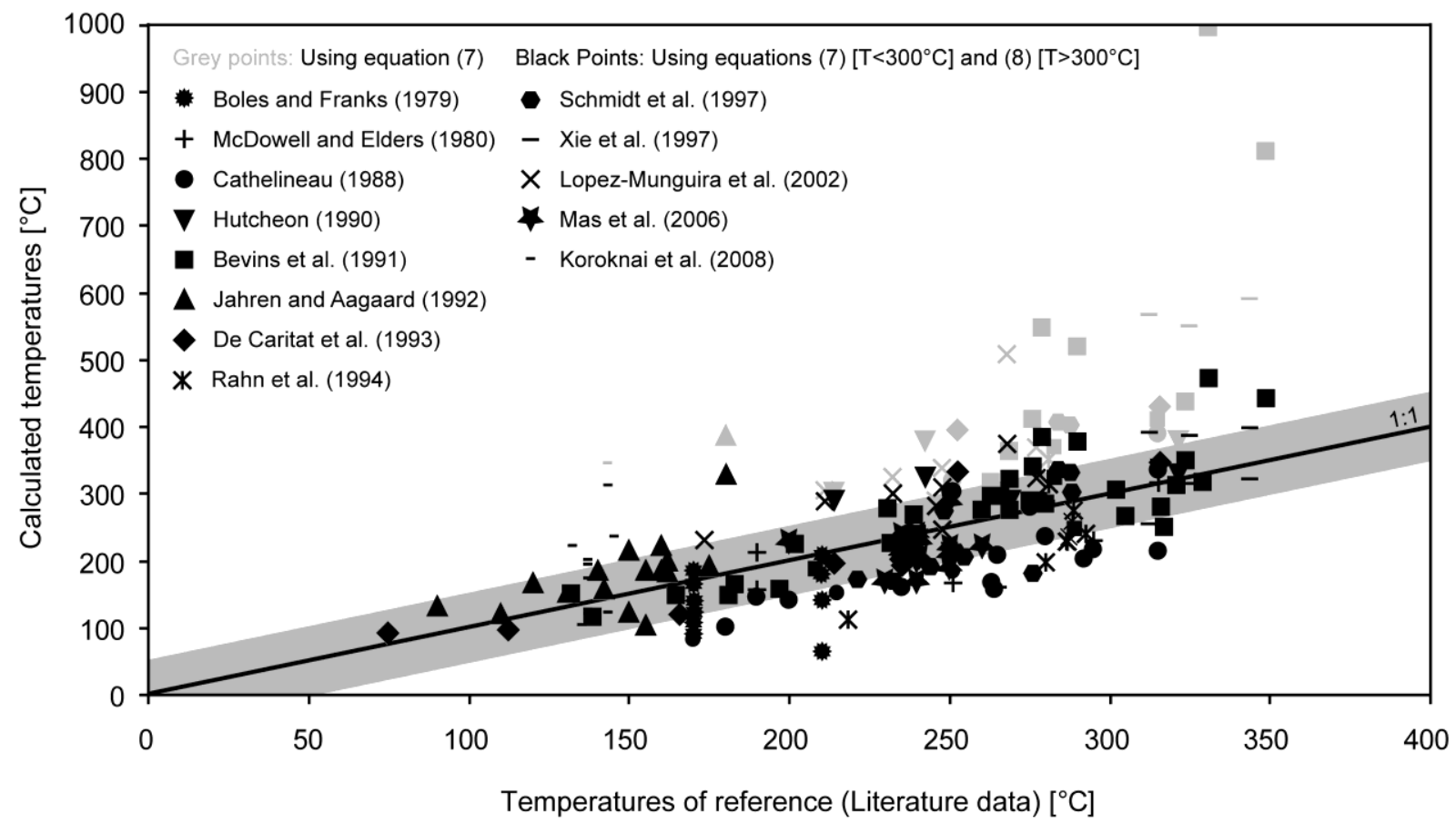

Fig. 2 Relationship between temperatures of reference (literature data) and temperatures

690 calculated with the new thermometer (161 analyses used for thermometer calibration, listed in

691 Table 1), considering the chemical composition of chlorites formed at $P<4$ kbar. Black

692 symbols: temperatures calculated with the linear equation (7) and the quadratic equation (8)

693 when $T>300^{\circ} \mathrm{C}$. Grey symbols: temperatures calculated with the linear equation (7) only.

694 The shaded zone indicates the $1: 1$ line $\pm 50^{\circ} \mathrm{C}$. See text for details

695

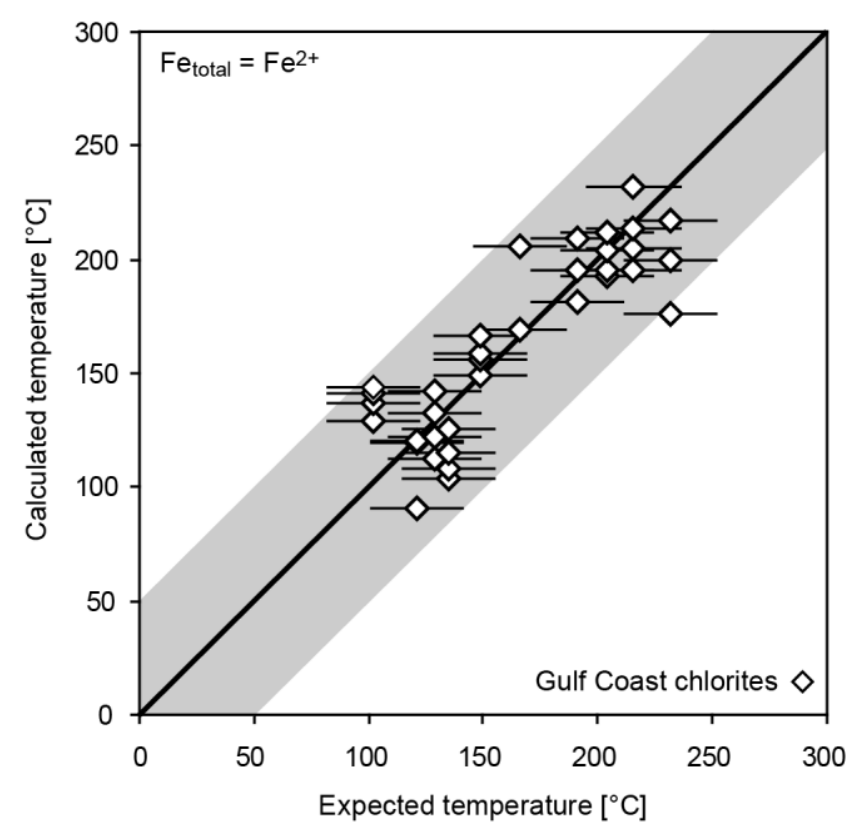


697 Fig. 3 Comparison of measured/expected temperatures $\left(\mathrm{BHT} \pm 20^{\circ} \mathrm{C}\right)$ for chlorites of the Gulf 698 Coast formation versus temperatures calculated using the new geothermometer (all $\mathrm{Fe}$ is 699 ferrous)

700

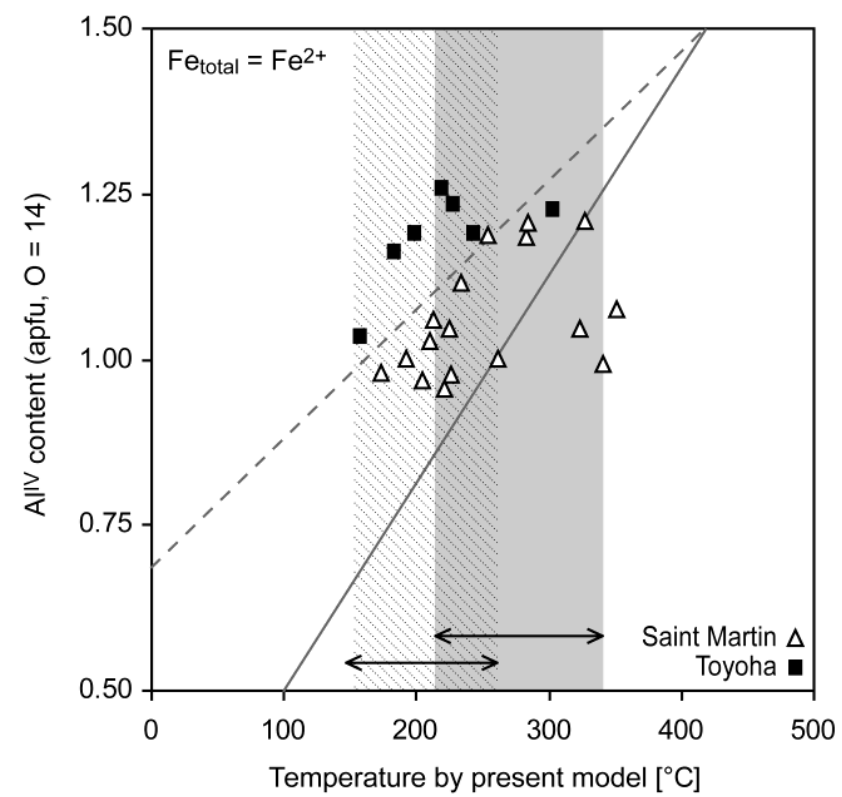

701

702 Fig. 4 Plot of tetrahedral Al contents versus calculated temperatures using the new

703 geothermometer (all Fe is ferrous) for Saint Martin and Toyoha chlorites. The range of

704 expected temperatures is indicated by the shaded area for St Martin chlorites, by the hatched

705 area for Toyoha chlorites. The solid and dashed curves are the equations of Cathelineau

706 (1988) and Hillier and Velde (1991) empirical thermometers, respectively 

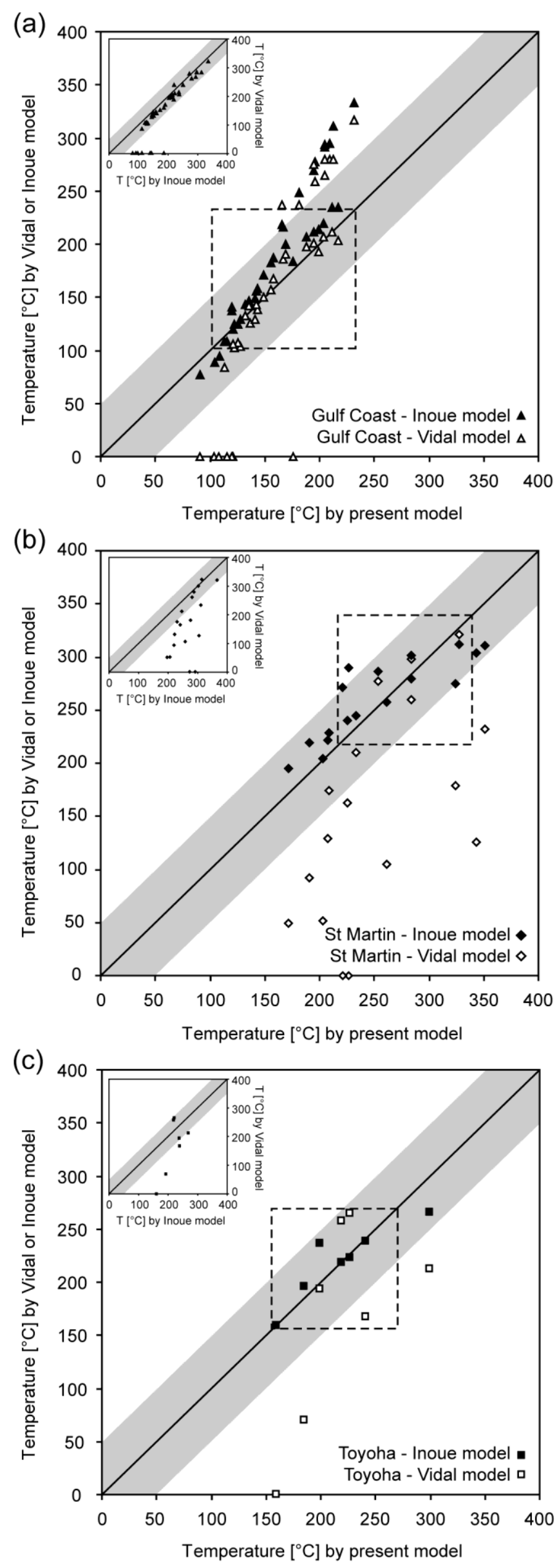
709 Fig. 5 Comparison of calculated temperatures using Inoue et al. (2009), Vidal et al. (2006)

710 and the present chlorite geothermometers. Solid and open symbols refer to temperatures

711 calculated by Inoue et al. (2009) and Vidal et al. (2006) models, respectively. Dashed

712 rectangular areas correspond to the expected temperature ranges for the Gulf Coast (a), Saint

713 Martin (b) and Toyoha (c) datasets. The shaded zone indicates the $1: 1$ line $\pm 50^{\circ} \mathrm{C}$.

714

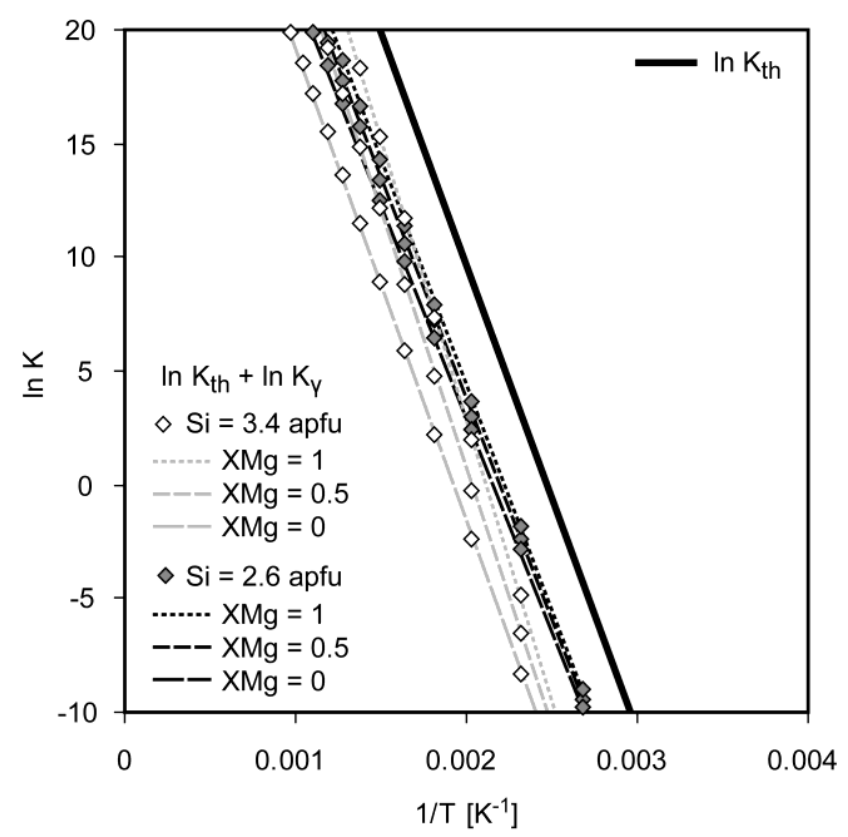

Fig. 6 Effect of non-ideality on $\ln K$, considering symmetric binary interactions, $\mathrm{X} \square=0.2$

717 apfu, $W(\mathrm{M} 2-\mathrm{M} 3)=0$ and various $\mathrm{Si}$ content and $\mathrm{XMg}$ ratio; modified after Bourdelle (2011).

718 The solid curve corresponds to the thermometer calibration (noted $\ln K_{t h}$ ), which is indicated 719 as reference and is calculated according to $1 / T$ (not from the fixed compositions). The

720 variations of $\mathrm{XMg}$ ratio affect only very slightly the slope of the $\ln K=f(1 / T)$ curve,

721 especially for the Si-poor composition case 